\title{
Perlas y piel de azabache. El negro en las pesquerías de las Indias Occidentales
}

Jean-Pierre Tardieu

Université de La Réunion

Poco después del Descubrimiento, las perlas de las Indias occidentales rivalizaron con las de Oriente para el adorno de las damas de la alta sociedad o de las Vírgenes más veneradas, suscitando la curiosidad científica de los cronistas más conocidos y una exigente legislación fiscal. Debido a las leyes emitidas a favor de los indios, éstos se sustituyeron en gran parte, en las pesquerías de perlas, por esclavos negros sometidos — por la codicia de los amos y el interés de la Corona- a despiadadas condiciones de vida y de trabajo que desembocaban las más veces en una muerte inexorable.

PALABRAs Claves: Perlas, Indias Occidentales, esclavos negros, deshumanización, muerte.

Not very long after the Discovery, the pearls from the West Indies competed with those from the Orient for the full regalia of the ladies of the gentry, or that of the most revered virgins, while raising the curiosity of the best known chroniclers and creating an excruciating tax system. Considering the legislation passed for the benefit of Indians, those were to a large extent replaced in the "pearl fisheries" by black slaves submitted by the covetousness of their masters and the interests of the Crown to horrendous living and working conditions which most of the time relentlessly led them to death.

Keywords: Pearls. West Indies. Black slaves. Deshumanization. Death.

En toda la Europa renacentista, solía la alquimia petrarquista transmutar las prendas de la dama amada en materias de particular delicadeza y natural pureza (lirio, azucena, rosa, etc.) o de gran valor (cristal, diamante, zafiro, rosicler, oro, marfil, perlas o aljófar). ${ }^{1}$ Quevedo no se contentó con transformar en perlas las lágrimas de Filis:

Ondea el oro en hebreas proceloso, corre el humor en perlas hilo a hilo, juntó la pena el Tajo con el Nilo, éste creciente cuanto aquél preciso ${ }^{2} \ldots$

1 La palabra aljófar, de una indudable connotación poética debida a su origen exótico (ar. alchauhara) y a su fonetismo, designa una pequeña perla.

2 Quevedo, Francisco de: "A Filis, que suelto el cabello lloraba ausencias de su pastor", en Obras completas, Aguilar, Madrid, 1978, t. 2, pág. 131. 
o el sudor de Diana de Éfeso:

Estábase la efesia cazadora dando en aljófar el sudor al baño, cuando en rabiosa luz se abrasa el año y la vida en incendios se evapora. ${ }^{3}$

Reactualizó el tópico, acerca de los tesoros de Lisi, situándolo en un contexto histórico muy sugestivo para un español de la época:

Si buscas perlas, más descubre ufana su risa que Colón en el mar de ellas. ${ }^{4}$

Y en el soneto "Retrato de Lisi que traía en una sortija", se lee:

Traigo todas las Indias en mi mano, perlas que en un diamante por rubíes pronuncia con desdén sonoro hielo. ${ }^{5}$

Con el descubrimiento del Nuevo Mundo, rivalizaron efectivamente muy pronto las perlas de las Indias Occidentales con las de Oriente ${ }^{6}$ por su cantidad y también por su calidad, tal la famosa Peregrina.

De ahí el interés particular de los cronistas del Nuevo Mundo que a lo largo de los siglos XVI y XVII ilustraron sus comentarios no sólo con las imprescindibles referencias literarias clásicas o con anécdotas llamativas destinadas a amenizarlos sino también con aspectos descriptivos que, andando el tiempo, se alejaron de lo fabuloso para privilegiar lo natural. Además, más aun que la explotación de las otras riquezas de América (oro, plata, caña de azúcar, etc.), la de los ostrales en las costas tropicales suscitó una quisquillosa legislación, en particular en la Recopilación de leyes de los Reynos de las Indias, que involucró a los pescadores, indios primero y luego esclavos negros. Estas dos fuentes de información suministran preciosos datos particularmente en cuanto a las condiciones de trabajo infrahumanas impuestas a los buzos serviles, poco valorizadas hasta ahora, que merecerán la atención de este trabajo. No se puede abarcar esta cuestión sin pág. 130 .

3 "Significa el mal que entra a la alma por los ojos con la fábula de Acteón", en ibidem,

4 "Procura cebar a la cudicia tesoros de Lisi", in: Quevedo, F. de : Obras completas, pág. 117.

5 Ibidem, pág. 122.

$6 \mathrm{Su}$ "oriente", o pureza del lustre anacarado, competía con el de las perlas de Oriente. 
contextualizarla debidamente. ${ }^{7} \mathrm{Al}$ fin y al cabo dan a entender estos textos que la "piel de azabache" no valía mucho frente a la diafanidad de las perlas de las islas de Cubagua, Coché, la Margarita, o del Archipiélago de las Perlas.

\section{De la antigüedad a la modernidad}

Varios cronistas de las Indias Occidentales, antes de proponer la información recogida sobre los ostrales, apelaron a su cultura clásica y en particular a las referencias sacadas de la Historia natural de Plinio el Viejo, sirviéndoles éstas de hipotexto. ${ }^{9}$ En 1516, en la tercera de las Décadas del Nuevo Mundo, capítulo X, Pedro Mártir de Anglería evocó las enseñanzas de Aristóteles y de Plinio sobre la crianza de las perlas. Según ellos, las conchas se nutrían de una especie de tomillo que formaba como prados en el fondo del mar. ${ }^{10}$ De Plinio, en su afán de captatio benevolentiae, tomó prestada José de Acosta en 1590 una anécdota muy llamativa acerca de dos perlas de gran valor pertenecientes a Cleopatra. La reina, después de apostar con Marco Antonio que gastaría en una cena más de cien mil ducados, echó en vinagre una de ellas y, disuelta la perla, se tragó el líquido. Con las dos mitades de la otra se hicieron zarcillos para la estatua de Venus en el Panteón. El emperador Claudio también dio en un banquete, a cada uno de sus invitados, una rica perla deshecha en este líquido. ${ }^{11}$

Hechas semejantes premisas, a la usanza de la época, varios cronistas realzaron el aspecto novedoso del descubrimiento de los ostrales perleros por Cristóbal Colón y sus émulos. El mismo descubridor le había concedido un espacio apreciable en la carta de 1498 a los Reyes Católicos con

7 A propósito de aspectos que no trataremos en este trabajo remitiremos a menudo a la obra de Enrique Otte: Las perlas del Caribe: Nueva Cádiz de Cubagua, Fundación John Boulton, Caracas, 1977.

8 La literatura clásica se valía del azabache como término comparativo para evocar el color del hombre negro. Véase: Tardieu, Jean-Pierre: Le Noir dans la Littérature Espagnole des XVI ${ }^{e}$ et XVII siècles, Tesis doctoral inédita, Bordeaux, 1977.

9 Plinio trata de las perlas en el libro IX de su Historia natural.

10 Anglería, Pedro Mártir de: Décadas del Nuevo Mundo, Ediciones Polifemo, Madrid, 1989, Década Tercera, capítulo X, pág. 239.

11 Acosta, José de: Historia Natural y Moral de las Indias, en Obras del P. José de Acosta, Estudio preliminar y edición del P. Francisco Mateos, BAE 78, Editorial Atlas, Madrid, 1954, pág. 108. El jesuita respeta escrupulosamente la anécdota que cuenta Plinio de las perlas de Cleopatra, convirtiendo tan sólo su valor de diez millones de sestercios en cien mil ducados. 
motivo de su tercer viaje, refiriéndose a Plinio, según el cual las perlas nacen "del rocío que cae en las hostias que están abiertas". ${ }^{12}$ A su modo de ver no podía menos de haber "infinitísimas hostias y muy grandes" en las costas de aguas quietas por las que iba navegando. Efectivamente abundaban en los manglares. Entre los adornos de las mujeres encontradas en la punta de la Aguja, precisó el 8 de agosto, que había "perlas o aljóbar ${ }^{13}$ finíssimas". Rescató buen número de ellas con el propósito de regalarlas a los reyes y convencerles de que tuvieran "este negocio en mucho". ${ }^{14} \mathrm{~A}$ falta de oro, buenas eran perlas.

Gonzalo Fernández de Oviedo, acerca de "la rica isla llamada Cubagua, ${ }^{15}$ que agora llamamos la isla de las Perlas" señaló en 1535 que "allí es la principal pesquería dellas en estas Indias". ${ }^{16}$ Mandó el Almirante a unos hombres, agrega el cronista, en persecución de una canoa de pescadores de perlas. Llegados a tierra, un marinero hizo pedazos de un plato de barro de Valencia, ${ }^{17}$ adornado con "figuras y pinturas", para trocar los cascos con sartas de perlas. Aprovechó el descubridor la ingenua benevolencia de estos indios rescatando una escudilla de perlas por pedazos de otro plato con el fin de ofrecerlas a los reyes, doña Isabel y don Fernando. Pensaba volver allí cuando fuera conveniente, manteniendo el secreto de su hallazgo. Sin contar con la indiscreción de los tripulantes, quienes, no bien volvieron a Palos, se fueron de la lengua, lo cual movió a uno de los armadores de Moguer, Pero Alfonso Niño, a poner rumbo a dicha isla con algunos de ellos. Se le concedió el permiso real con tal de que no se acercase a más de cuarenta leguas de lo descubierto por el genovés. Como era de suponer

12 Plinio, Historia natural : "Origo atque genitura conchae est haud multum ostrearum conchis differens. Has ubi genitalis anni stimularit hora, pandentes se quadam oscitatione impleri roscido conceptu tradunt, grauidas postea eniti, partumque concharum esse margaritas pro qualitate roris accepti."

13 "Aljóbar" por "aljófar".

14 Colón, Cristóbal : Textos y documentos completos, Edición de Consuelo Varela, Alianza Editorial, Madrid, 1992, págs. 397-399, 406. Hernando Colón evocó la escena de una manera muy escueta sin ocultar por ello el interés de su padre: "Las mujeres llevaban sartas de cuentas en los brazos, y en ellas perlas grandes y pequeñas, muy bien engarzadas, de las que se rescataron algunas para mandarlas como muestra a los Reyes Católicos. Siendo preguntados dónde hallaban aquellas cosas, dijeron por señas que en las conchas de las ostras que pescaban al poniente de la tierra de Gracia y detrás de ésta hacia el Norte. Por lo cual el Almirante se detuvo allí, para tener más certeza de tan buena muestra, y mandó las barcas a tierra ... “, en: Historia del Almirante, Ed. de Luis Arranz Márquez, Dastin, S L, Madrid, 2000, pág. 240.

15 La isla de Cubagua se sitúa en la costa de Venezuela, en el canal que separa la isla Margarita del continente, al oeste de la isla de Coche, a la que también aludiremos (ver mapas).

16 Fernández de Oviedo, Gonzalo: Historia General y Natural de las Indias, Edición y estudio preliminar de Juan Pérez de Tudela Bueso, BAE 117, Editorial Atlas, Madrid, 1952, pág. 59.

17 Estos platos también se llamaban "de Málaga". 
no respetó lo pactado y volvió a España con un pingüe rescate conseguido a trueque de alfileres, cascabeles y objetos de escaso valor. Después de tomar tierra en Galicia, algunos de sus socios manifestaron su disconformidad por un pretendido mal reparto de las perlas y un fraude en el quinto real. Enterado de la noticia, el virrey Hernando de Vega ordenó su detención, decidiendo la Corona poner "grand recabdo en la isla". ${ }^{18}$ Según Francisco López de Gómara, quien en 1552 refirió los hechos de una manera muy parecida, se olvidó el Almirante de informar a tiempo a los reyes del "descubrimiento de las perlas", "lo cual fue gran parte que los Reyes Católicos se enojasen y lo mandasen traer preso a España". ${ }^{19}$

Anglería trata de la primera entrega de una gran cantidad de perlas por el rey de la Isla Rica en el archipiélago llamado posteriormente de las Perlas, en la costa del Pacífico. A Gaspar de Morales, emisario del gobernador de Castilla del Oro Pedrarias Dávila, le dio "un canasto elaborado con sumo arte y lleno de perlas" a cambio de sartas de cristal, espejos, cascabeles de latón y alguna segueta de hierro. Por si fuera poco, asevera el cronista, le prometió el cacique al capitán español cuantas perlas apeteciese siempre y cuando le conservase su amistad porque "de perlas [estaban] llenas todas las costas profundas de todas las islas que [veía]". ${ }^{20}$

A decir verdad, la escena fue menos idílica de lo que cuenta Anglería. En una carta dirigida al rey el 16 de octubre de 1515, Vasco Núñez de Balboa, descubridor del Mar del Sur, aludió a la terrible represión con que castigó Gaspar de Morales la resistencia opuesta por el cacique, matándole a un centenar de súbditos y quemándole "la mitad de las casas y el maíz que tenía dentro". A pesar de someterse el jefe indio, de darles una gran cantidad de perlas a los españoles y de llevarles adonde las cogían, el capitán redujo a esclavitud a todos los isleños. Una de estas perlas hubiera sido digna de pertenecer al rey por su perfección, de no haberla comprado en almoneda un mercader por mil doscientos pesos de oro. ${ }^{21}$ La crónica de F. López de Gómara facilita más información al respecto. Allí, enfatiza, "había grandes pesquerías de perlas, y eran las mayores y mejores del Mundo Nuevo", prosiguiendo:

18 Fernández de Oviedo, G.: Historia General y Natural de las Indias, BAE 118, pág. 191.

19 López de Gómara, Francisco : Primera y segunda parte de la Historia General de las Indias, en Historiadores primitivos de Indias, Colección dirigida e ilustrada por Don Enrique de Vedia, t. 1, BAE 22, Editorial Atlas, Madrid, 1946, pág. 203.

20 Anglería, P. M. de: Décadas del Nuevo Mundo, pág. 238.

21 AGI, Patronato, 26, R. 5 (5), fs. 32r-34v, en Tovar Pinzón, Hermes: Relaciones y Visitas a los Andes. S. XVI, Colección de Historia de la Biblioteca Nacional, Santa Fé de Bogotá, 1953, pág. 84. 
"Muchas de las perlas que dio el Cacique eran como avellanas, otras como nueces moscadas, y una hubo de veinte y seis quilates, y otra de treinta y uno, hechura de cermeña, muy oriental y perfectísima, que compró Pedro del Puerto, mercader, a Gaspar de Morales en mil y docientos castellanos, el cual no pudo dormir la noche que la tuvo, de pensamiento y pesar por haber dado tanto dinero por una piedra; y así la vendió luego el siguiente día a Pedrarias de Ávila para su mujer doña Isabel de Bobadilla, en lo mesmo que le costó; y después la vendió la Bobadilla a la emperatriz doña Isabel".22

Se trataba de la famosa Peregrina que, lo veremos a continuación, marcó hondamente las mentalidades.

El mismo Núñez de Balboa, el 17 de octubre de 1513, se había lanzado a la conquista de dichas islas con sesenta hombres. A los dos días de una peligrosa navegación en canoas, desembarcaron de noche en el territorio del cacique Tumaco, quien consiguió huir. En los bohíos vieron numerosas perlas y muchas conchas recién pescadas en isletas cercanas. ${ }^{23}$ A esta provincia, llamada Chitarraga por los naturales, le dieron los españoles el nombre de San Lucas. La isleta más rica en perlas según los indios era Toe, o, por otro nombre, Terarequí. Por andar el mar bravo, no tuvo Núñez de Balboa la oportunidad de dirigirse a la isla que llamó Isla Rica. ${ }^{24}$ De este lugar procedieron la Peregrina, una perla de treinta y un quilates, ${ }^{25}$ comprada después por Isabel de Portugal, esposa del emperador, y otra, de veintiséis, que vio el mismo Fernández de Oviedo. ${ }^{26} \mathrm{~A}$ su parecer, en estas islas, con más trabajo que en Cubagua, por situarse en aguas más profundas, se hallarían mayor cantidad de perlas y de más peso. ${ }^{27}$ Pero según el

22 López de Gómara, F : Primera y segunda parte de la Historia General de las Indias, pág. 280.

23 Según F. López de Gómara, Tumaco habría dicho a Núñez de Balboa, después de aceptar entrevistarse con él, que "su riqueza era nada en comparación del rey de Terarequi, isla abundantísima de perlas, que cerca estaba, el cual tenía perlas mayores que un ojo de hombre, sacadas de ostiones tamaños como sombreros". Añade el cronista que "algunas de las de Tumaco eran negras, otras verdes, otras azules y amarillas, que debía ser por parte" ; López de Gómara, F.: Primera y segunda parte de la Historia General de las Indias, pág. 195. Es una de las pocas alusiones a los colores de las perlas que hemos encontrado.

24 Fernández de Oviedo, G. : Historia General y Natural de las Indias, págs. 216-217.

25 El quilate, del árabe qirat (peso), unidad de peso también empleada para el comercio de las perlas, equivalía a 0,2118 gramos.

26 La emperatriz dio la orden de compra de las dos perlas en 14 de enero de 1532: "una grande, de pera punxante, e otra menor chata, a forma de panesillo, en novecientos mill maravedis". Efectuarían el pago los oficiales de la Caja Real de Nicaragua. Véase: Colección de documentos inéditos relativos al descubrimiento, conquista y organización de las antiguas posesiones españolas de América y Oceanía (en adelante CDIRDCO), Madrid, 1864-1884, t. XII, págs. 492-496.

27 Juan de Solórzano y Pereyra (1575-1655) se refiere a esta evocación en su Política indiana, libro VI, cap. IV, Edición de M. A. Ochoa Brun, BAE 255, Editorial Atlas, Madrid, 1972, págs. 329-331. 
jesuita José de Acosta (1590), se sacaban las mejores perlas en el Mar del Norte, cerca del río de la Hacha. ${ }^{28}$ En 1653, su colega Bernabé Cobo, respecto a las pesquerías del Mar del Sur, estipuló que sus perlas perdían el lustre e incluso quedaban oscuras y chamuscadas al horadarlas los indios con fuego. ${ }^{29}$

Bartolomé de Las Casas, por supuesto, no hizo caso omiso de la empresa de Gaspar de Morales, ${ }^{30}$ a cuyo lado estaba Francisco Pizarro, futuro conquistador del Tawantinsuyu. Buen pretexto de indignación le deparó efectivamente su comportamiento para con los indios. ${ }^{31}$ Entre las perlas del cacique sometido había, según el fraile, una del tamaño de una nuez pequeña, e incluso, a decir de ciertos, de una pera cermeña. ${ }^{32}$ Era, por supuesto, la Peregrina. ${ }^{33}$

Pizarro, en las capitulaciones de Toledo firmadas el 26 de julio de 1529, se hizo atribuir el usufructo de Flores, una de las islas del Archipiélago de las Perlas, ${ }^{34}$ a cambio de doscientos mil maravedíes anuales pagados al fisco real, además del quinto del oro y de las perlas extraídas, comprometiéndose por otra parte a no emplear indios en la pesca. ${ }^{35} \mathrm{Ya}$ no ignoraba la Corona las duras condiciones de trabajo impuestas a los naturales en estos lugares, aspecto al que volveremos a continuación. Si el conquistador no pudo sacar fruto de su experiencia en la materia, sus segui-

28 Acosta, J. de : Historia Natural y Moral de las Indias, pág. 108.

29 Cobo, Bernabé: Historia del Nuevo Mundo, en Obras del P. Bernabé Cobo S. J., Estudio preliminar y edición del P. Francisco Mateos, BAE 91, Editorial Atlas, Madrid, 1964, pág. 132.

30 El episodio de Gaspar de Morales y de la Peregrina constituye un buen ejemplo de intertextualidad al nivel de las crónicas referidas en este trabajo. Entrando en materia, veremos que no faltan otros, en relación con el mismo tema.

31 Se había olvidado el padre, quizá un poco rápidamente, que cuando era tan sólo "el clérigo Las Casas", había obtenido de la Corona en las capitulaciones para su experiencia de colonización pacífica en Cumaná (19 de mayo de 1520) el permiso de "ir a rescatar perlas a la pesquería de las perlas que agora está descubierta", con ciertas condiciones fiscales ventajosas hasta el final de su vida. Véase: $C D I R D C O$, t. VII, págs. 73-74. Es de suponer que él y sus cincuenta compañeros, frente a los indios pesqueros, no se hubieran portado como los dueños de canoas cuya actitud denunció más de dos decenios después.

32 La cermeña es una variedad de pera muy pequeña. Según Plinio, estas perlas se llamaban “elenchi”. Veremos más abajo que Garcilaso de la Vega reutilizó la comparación conocida ya en la época del dominico.

33 Las Casas, Bartolomé de: Historia de las Indias, in: Obras escogidas de fray Bartolomé de las Casas, Edición de Juan Pérez de Tudela Bueso, BAE 96, Editorial Atlas, Madrid, 1961, Libro tercero, cap. LXV, pág. 326.

34 El Archipiélago de las perlas (Panamá), en la costa del Pacífico, consta de 39 islas mayores, 63 más pequeñas y 82 islotes (ver mapas). pág. 196.

35 Vargas Ugarte, Rubén: Historia General del Perú, Carlos Milla Batres, Lima, 1966, t. 1, 
dores no abandonaron toda esperanza de hallar perlas por las costas del Perú. Informado el virrey Francisco de Toledo de que las había en el litoral de Manta y de Puerto Viejo, en la Real Audiencia de Quito (actual Ecuador), exigió muestras del corregidor de Guayaquil. Le parecieron menudas, oscuras y de poco valor. Sin embargo ya se había organizado la pesquería con barcos y negros procedentes de Panamá. La Corona, el 2 de diciembre de 1578 , le dejó entera libertad a este respecto con tal de que siguiese los consejos de "personas inteligentes" en el asunto. ${ }^{36}$

El descubrimiento de las perlas de Terarequí dejó una profunda huella en la memoria de los descubridores, en particular en la de Hernando de Soto, compañero de Pizarro. En su empresa de la Florida dio con gran cantidad de perlas en los templos que servían de sepulturas a los jefes, como el de la señora de Cofachiqui, según refiere el Inca Garcilaso de la Vega:

"Todas las arcas grandes y chicas estaban llenas de perlas y aljófar. Las perlas estaban apartadas unas de otras. Por sus tamaños estaban en las arcas, que las mayores estaban en las primeras arcas, y las no tan grandes en las segundas, y otras más chicas, en las terceras, y así, de grado en grado, hasta el aljófar, el cual estaba en las arquellas más altas. En todas ellas había tanta cantidad de aljófar y perlas que por vista de ojos confesaron los españoles que era verdad y no soberbia ni encarecimiento lo que la señora de este templo y entierro había dicho, que, aunque se cargasen todos ellos, que eran más de novecientos hombres, y aunque cargasen sus caballos, que eran más de trescientos, no acabarían de sacar del templo las perlas y aljófar que en él había".

Es obvia la exageración, pese a lo dicho, pero correspondía a una realidad: en los siglos anteriores los indios, con motivo de los ritos funerarios, fueron acumulando perlas en los templos sin ninguna finalidad de atesoramiento. Sin embargo perdían mucho de su lustre con las condiciones de extracción. El cacique de Ychiola enseñó a los españoles de la expedición cómo se efectuaba. En cuanto volvieron las canoas que había mandado a pescar, echaron los indios las conchas sobre las brasas de una hoguera encendida poco antes. Así se abrieron y se recogieron diez o doce perlas del tamaño de garbanzos medianos, de una gran perfección, al no haber perdido su color natural con el calor del fuego. ${ }^{37}$

36 AGI, Lima, 570, Registros de oficio, L. XIV, fol. 189r.

37 Garcilaso de la Vega el Inca, Historia de la Florida, en Obras completas del Inca Garcilaso de la Vega, Edición y estudio preliminar del P. Carmelo Saenz de Santa María, S. J., BAE 182, Editorial Atlas, Madrid, 1965, págs. 381-391. 
Las perlas de valor, procedentes a menudo del archipiélago del mismo nombre, vinieron a superar al oro y a la plata en las representaciones imaginarias colectivas como mejor exponente de éxito en las empresas indianas, habida cuenta de que, desde la antigüedad, sólo la gente pudiente podía adquirirlas. Juan de Solórzano y Pereyra ofrece a sus lectores una anécdota novelesca de no poco interés. Don Joseph de los Elguiros, dueño de una ranchería en una isleta del Mar del Sur, embarcó muchas perlas en la flota para pagar deudas al fisco real. Hundiose la capitana en un combate con los ingleses, escapando la almiranta llevando a bordo una perla suya de cincuenta y nueve quilates que, con otras joyas, recibió la Corona como pago de los intereses debidos. Tenía la perla, comenta el cronista, forma de aguacate y excedía por su perfección a la Peregrina. Los oficiales del fisco real de Panamá le tenían embargada con el mismo motivo a Elguiros otra perla de veintinueve quilates. ${ }^{38}$

\section{De lo fabuloso a lo natural}

Dentro de los límites de los conocimientos científicos de la época, la racionalidad de los cronistas intentaba presentar una explicación lógica a un fenómeno que rayaba en lo maravilloso. El humanista Anglería, hablando de la experiencia de Gaspar de Morales, alude a la creencia de que las perlas salen de la matriz de la concha, después de chupar en el útero las ubres de su madre, como los huevos salen del ovario de una gallina. ${ }^{39}$ Fernández de Oviedo, buen conocedor del medio ambiente, rechaza los dichos de Plinio según los cuales las conchas perleras, como las abejas, forman enjambres guiados por un rey de modo que, para hacer una buena pesca, hay que tomar la concha principal. ${ }^{40}$ En cambio acepta la proposición del naturalista latino referente al crecimiento de las perlas fuera de la concha. Agrega un detalle en relación con su propia observación en Cubagua: el "humor rojo o sanguíneo" producido por las ostras en cierto tiempo, que tiñe las aguas, correspondería a su menstrúo. Tendría algo que ver el fenómeno, es de suponer, con la presencia en las aguas tropicales de cierta cla-

38 Solórzano y Pereyra, J. de, Política indiana, págs. 329-331.

39 Anglería, P. M. de : Décadas del Nuevo Mundo, pág. 239.

40 Plinio, Historia natural: "Quidam tradunt sicut apibus, ita concharum examinibus singulas magnitudine et uetustate praecipuas esse ueluti duces, mirae ad cauendum sollertiae. Has urinantium cura peti, illis captis facile ceteras palantis retibus includi ...". 
se de microcóspicos monocelulares semejantes al alga roja (dumaliella salina). ${ }^{41}$ La minuciosa descripción facilitada por el cronista de las diferentes formas de ostras en Cubagua y de sus modos de adhesión a las rocas se debe más a sus dotes de buen observador que a sus recuerdos de Plinio. ${ }^{42}$ López de Gómara volvió sobre el tema del parto de perlas por las ostras, afirmando que no creía en esto, aunque "bien es verdad que a cierto tiempo del año se tiñe algo la mar en Cubagua, donde más perlas se han pescado, y de allí arguyen que desovan, y que les viene su purgación como a mujeres". ${ }^{43}$

La abundancia de las perlas en América, afirma Acosta, les hizo perder el prestigio de que gozaban en la antigüedad: entonces "eran tenidas por cosa que sólo a personas reales pertenecían". Para evidenciar la evolución, se vale el jesuita de una paradoja significativa sosteniendo que "hasta las negras traen sartas de perlas". ${ }^{44}$ No se tachará de inverosímil la alusión, de indudable viso satírico, si se tiene en cuenta la legislación indiana al respecto, según la cual ciertas esclavas, debido a circunstancias reprobadas por la moral colonial, manifestaban una afición compensatoria por el lujo. Dicho esto, vuelve Acosta a referencias naturales, enumerando la gran diversidad de forma, de color y de perfección que justificaba las diferencias de estimación. Sin embargo, aprovecha la ocasión con un rasgo humorístico: "Unas llaman Avemarías, por ser como cuentas pequeñas de rosario; otras Paternostras, por ser gruesas". ${ }^{45}$

Fernández de Oviedo suministra datos muy pertinentes desde el punto de vista naturalista:

"La isla de Cubagua [...] es llana, e el terreno en sí es salitral, y por tanto estéril de todo género de buenas hierbas. Ni tampoco hay árboles en ella, sino algunos de guayacán, pequeños o enanos al respecto de los que en otras partes destas Indias hay. Otros arbolecillos hay bajos, a manera de zarzales".

Luego enumera el cronista los pocos animales que pueblan la isla, como conejos y aves marítimas. Los habitantes traen el agua de Cumaná y

41 El alga roja dumaliella salina, en la que se concentran los pigmentos carotenoideos, según la salinidad de las aguas, es presa de una diminuta gamba (artemia salina) de que se nutren los flamencos rosados (phaenicopterus ruber), en particular en las Antillas y en Suramérica, y a la que deben su color.

42 Fernández de Oviedo, G.: Historia General y Natural de las Indias, BAE 118, pág. 207.

43 López de Gómara, F.: Primera y segunda parte de la Historia General de las Indias, pág. 280.

44 E. Otte cita esta evocación de Acosta, Las perlas del Caribe..., pág. 26.

45 Acosta, J. de: Historia Natural y Moral de las Indias, pág. 108. 
la leña de la Margarita. ${ }^{46}$ López de Gómara, López de Velasco y por fin Herrera a principios del siglo XVII se inspiraron en Fernández de Oviedo para describir la esterilidad de la isla. ${ }^{47}$ Parecía como si la producción de perlas en sus costas fuera una compensación a su extrema aridez, originada por el salitre, que hacía muy penosa la vida humana en este reducido espacio insular.

Esta descripción del adusto ecosistema de Cubagua aclara en qué circunstancias trabajaban los pescadores indios y luego negros. ${ }^{48}$ Poco dice Herrera sobre las mismas perlas sino que nacen de un granillo, "tierno como leche", que va creciendo y endureciéndose con el tiempo. ${ }^{49}$ Prefiere poner el énfasis en el beneficio sacado por el fisco real de las pesquerías que algunos años alcanzaba los quince mil ducados. ${ }^{50}$

El Inca Garcilaso de la Vega adopta una actitud parecida, haciendo hincapié en la venta en 1564 del quinto real de perlas por remate en la hispalense Casa de Contratación, que dio lugar a especulación por parte de los mercaderes. En Sevilla conoció en 1562 o 1563 a un aventurero arruinado por su afición al juego. Tiempo atrás, disfrutando de más de treinta mil ducados adquiridos en el comercio indiano de perlas, le había hecho a su novia una saya adornada con una ancha bordadura de perlas finas de un valor de cuatro mil ducados. Buena parte de las perlas del quinto real, sigue diciendo el cronista mestizo, se empleaba en el culto como por ejemplo el adorno del manto y de la saya de la imagen de Nuestra Señora de Guadalupe. Cuenta también de una famosa perla de Panamá dedicada a Felipe II por un caballero llamado don Diego de Temez, que pudo ver en Sevilla en 1579: $192-194$

46 Fernández de Oviedo, G.: Historia General y Natural de las Indias, BAE 118, págs.

47 López de Gómara, F.: Primera y segunda parte de la Historia General de las Indias, pág. 205; López de Velasco, Juan : Descripción universal de las Indias (comp.: 1571-1574), Edición de don Marcos Jiménez de la Espada, estudio preliminar de doña María del Carmen González Múñoz, BAE 248, Editorial Atlas, Madrid, 1971, pág. 72; Herrera y Tordesillas, Antonio de : Historia general de los hechos de los castellanos en las islas y Tierra Firme del mar Océano o Décadas (16011615), Edición y estudio de Mariano Cuesta Domingo, Universidad Complutense, Madrid, 1991, t. 1, pág. 504.

48 Este ecosistema lo describe acertadamente Otte, E.: Las perlas del Caribe ..., págs. 285-288. Son muy significativas las fotos aéreas que presenta en su libro.

49 A pesar de su brevedad, esta anotación se aproxima a la realidad. Es sabido que la perla tiene como origen un parásito que va cubriendo capas de carbonato de calcio.

50 Herrera, A. de: Historia general de los hechos de los castellanos en las islas y Tierra Firme del mar Océano o Décadas, pág. 504. 
"Era la perla del tamaño y talla y manera de una buena cermeña, tenía su cuello levantado hacia el pezón, como lo tiene la cermeña o la pera; también tenía el huequecito de debajo en el asiento. El redondo, por lo más grueso, sería como un hueso de palma de los grandes".

Según la estimación del lapidario real, el milanés Jácomo de Terenzo, valía entre catorce mil y cincuenta mil ducados, lo cual significaba que no tenía precio, "porque era una sola en el mundo, y así la llaman la peregrina". La confundió el cronista, según parece, con la perla vendida por la mujer de Pedrarias Dávila a la madre del rey, a no ser que la segunda quitara el nombre a la primera por su superioridad en perfección. De creer el rumor, el dueño de la pesquería manifestó su agradecimiento al negrillo descubridor concediéndole la libertad. Y el mismo pudo reivindicar la vara de alguacil mayor de Panamá. Lo escrito por Garcilaso de la Vega, si se aleja de la mera observación, permite, a diferencia de las anotaciones de su inspirador en la materia, o sea el padre Acosta, aquilatar debidamente lo que representaba el comercio de las perlas en la economía peninsular. ${ }^{51}$

El jesuita Bernabé Cobo, en su descripción del Nuevo Mundo publicada en 1653, se aparta de estas consideraciones anecdóticas para fijarse en la naturaleza de las perlas, muy diferentes unas de otras en el tamaño, en la forma y en el color, de manera que dos perlas parecidas alcanzan un precio superior. Se suelen pescar entre cuatro y doce brazas de hondo. Pero en las costas de Panamá se descubren conchas en bajamar que se abren para recibir el sol, de lo cual fue testigo el propio cronista. Las perlas están encajadas en la carne de las ostras, "como los nudos en la tabla". El aspecto exterior de las conchas perleras, tosco y áspero, no las diferencia de las demás. En cambio, por dentro, su lustre, aunque más oscuro, se parece al de las perlas. Los negros pescadores, limando las asperezas de la costra con una piedra, consiguen un nácar lustroso con que hacen cucharas. Sus dueños les dan permiso para venderlas "para alivio del excesivo trabajo que pasan en aquel oficio". ${ }^{52}$

\section{De los ostrales al quinto real}

Con lo dicho en cuanto a los beneficios procedentes del quinto real, se entiende la atención de la Corona por el control de la pesca. No costaba

51 Garcilaso de la Vega, Comentarios Reales de los Incas (1609), en Obras completas... págs. 326-328.

52 Cobo, B.: Historia del Nuevo Mundo, pág. 133. 
mucho trabajo efectivamente engañar a los oficiales reales, dado lo diminuto de las perlas que, además, no necesitaban, para ser comercializadas, de una compleja transformación como los minerales de oro o de plata. La Recopilación de leyes de los Reynos de las Indias de Carlos II reúne las reales cédulas despachadas en torno a tal actividad hasta fines del siglo XVII. ${ }^{53}$

Para buscar una pesquería, o sea para efectuar un "descubrimiento de ostiales $^{54}$ de perlas", se necesitaba una licencia del gobernador y de los oficiales reales del lugar, según cédula de Fernando de Aragón con fecha del 10 de diciembre de 1512.5 Se obligarían los "vecinos y moradores" que se dedicasen a ello a abonar el quinto real, reservando las mejores perlas para la Corona, la cual las pagaría con los fondos suministrados precisamente por el mismo quinto real o de cualquier otra manera (Lib. IV, tít. XXV, ley XXIX). Reanudaron estas disposiciones Carlos Quinto el 24 de noviembre de 1525 y luego Felipe IV el 19 de junio de 1627 (Lib. IV, tít. XIX, ley II). Se concedía a los indios idéntica facultad, con las correspondientes obligaciones, como vasallos libres de la Corona (ibidem., ley XXX). ${ }^{56}$

Los dueños de canoas de Margarita ${ }^{57}$ vieron las ventajas que podían sacar de los apuros financieros de la Corona. Su procurador general, Pedro Luis de Vargas, personaje de quien volveremos a hablar, hizo hincapié en los inconvenientes que acarreaba para el erario real el secuestro por deudas de las canoas, de los negros de conchas y de los aparejos cuando iba progresando la pesquería y por ende la fiscalidad. No le costó trabajo convencer al Consejo de Indias, dictando el rey el 12 de octubre de 1588 una cédula que se opuso a tal medida en la isla "teniendo los dueños de ello otros bienes cuantiosos en que pueden ser ejecutados". ${ }^{8}$ Extendió la provisión

53 Las referencias que vienen a continuación se sacan de la Recopilacion de Leyes de los Reynos de las Indias mandadas imprimir y publicar por la Magestad Católica del Rey Don Carlos II Nuestro Señor, Madrid, 1791, por la Viuda de D. Joaquín Ibarra. Edición facsímil coeditada por el Centro de Estudios Políticos y Constitucionales y el Boletín Oficial del Estado, Imprenta Nacional del Boletín Oficial del Estado, Madrid, 1998.

54 "Ostiales", arcaísmo por "ostrales".

55 La ley reanudó la real cédula despachada en 10 de diciembre de 1512 que hacía obligación a los vecinos de las islas de La Española y de San Juan de obtener para ir a pescar perlas el permiso del almirante Diego Colón y de los jueces de apelaciones (oidores de la Real Audiencia). Véase: CDIRD$C O$, t. 9, págs. 3-4.

56 La ley corresponde a la real cédula de 2 de diciembre de 1578 dirigida al gobernador y a los oficiales de la Real Hacienda de la isla de la Margarita. Véase: Registros de oficios y partes, reales órdenes, resoluciones, etc. para las autoridades y particulares de la provincia de Venezuela-1533-1604 (en adelante ROPV). Investigaciones Hmno. Nectario María, AGI, Sala de Investigadores, t. 2, pág. 64.

$57 \mathrm{La}$ isla, situada a $38 \mathrm{kms}$. de la costa de Venezuela, frente a la ciudad de Cumaná, debe su nombre al término usado por los griegos (margarita) para hablar de las perlas.

58 ROPV, t. 2, págs. 222-223. 
Felipe II el 20 de febrero de 1593 a todas las pesquerías. De ninguna manera se podrían secuestrar por motivo de deuda las canoas, los aparejos y los negros, exactamente como pasaba con los esclavos y las herramientas de los mineros (Lib. V, tít. XIV, ley II).

Encargó Carlos II a los gobernadores la vigilancia de las rancherías de ostrales, ${ }^{59}$ conformadas por varios dueños de canoas, donde vivirían los españoles, los indios y los negros que trabajasen en ellas de manera que pudiesen socorrerse mutuamente en caso de peligro y la seguridad de las embarcaciones en surgideros cercanos a las rancherías (Lib. IV, tít. XXV, ley I). El 24 de mayo de 1579, ya había previsto Felipe II la construcción en dichos lugares de casas fuertes para defenderlos de los corsarios. ${ }^{60} \mathrm{En}$ estos locales se dedicaría un cuarto para la caja de tres llaves de la Hacienda real, y otro para el depósito de las conchas pescadas. En él y en presencia de los oficiales reales, se sacarían las perlas en la forma dispuesta por la legislación, como veremos a continuación (lib. IV, tít. XXV, ley II).

De creer a Pedro Luis de Vargas, procurador general de la Margarita, los corsarios, con canoas y piraguas rápidas, conseguían introducirse en las pesquerías, robando y quemando sin mucha dificultad. Con este motivo suplicó al rey que se construyese en el puerto más adecuado una fortaleza, para lo cual se pidió el parecer del presidente de la Real Audiencia de Santo Domingo, el 23 de septiembre de $1586 .{ }^{61}$ La defensa de la isla fue uno de los principales temas evocados por los procuradores, según consta por ejemplo en la carta del monarca al gobernador con fecha de 5 de junio de 1591.62 Le informaba de la petición del licenciado Francisco Manso de Contreras de reclutar a dos centinelas para la vigilancia de la costa desde atalayas. La Corona aceptó en principio a condición de que el gobernador y el Cabildo se las arreglasen para pagar la mitad de su sueldo. ${ }^{63}$ Incluso recibió el gobernador el título de capitán general, como aparece para don

59 Véase la organización de las rancherías en Otte, E.: Las perlas del Caribe ..., págs. 45-48

60 En su hoja de servicios de 28 de julio de 1653, el licenciado don Jacinto de Castelví y Lerma, clérigo, aseguró que su padre don Melchor March de Castelví se ilustró en el río de la Hacha, donde, con catorce soldados, resistió al inglés defendiendo la entrada de la casa donde estaban las arcas de perlas y los esclavos pescadores. AGI, Lima, 334.

$61 R O P V$, t. 2, págs. 187-188.

62 E. Otte trata de la construcción de una fortaleza en Cumaná que se decidió en 1522 ; Las perlas del Caribe ..., págs. 235-250.

$63 R O P V$, t. 2, págs. 267-268. 
Juan Sarmiento de Villandrando el 15 de mayo de $1592 .{ }^{64}$ Decidieron los vecinos mandar un barco a Sevilla en 1596 para comprar artillería, municiones y pólvora, con otros géneros destinados a las canoas. ${ }^{65}$ No bastaban sus esfuerzos para alejar el peligro y Juan Sánchez Malaver, procurador de turno, solicitó del Consejo de Indias una ayuda de ciento cincuenta soldados para la futura fortaleza, sin contar con la pólvora, el plomo, los arcabuces, los mosquetes necesarios, ocho piezas de artillería con tres artilleros, las herramientas y los esclavos imprescindibles para la construcción. Como era de esperar, se pidió más información al respecto al gobernador don Pedro Fajardo en 1597. ${ }^{66}$ En 11 de noviembre, se dio orden al presidente de la Casa de Contratación de Sevilla de mandar a la isla ocho piezas de artillería, con mosquetes y cierta cantidad de plomo y pólvora renovable cada año, ${ }^{67}$ siendo avisados de ello los oficiales reales de la isla por carta de 30 de octubre de 1600. El documento fijó el sueldo de los dos artilleros que acompañarían estas armas en diez ducados mensuales cada uno. ${ }^{68}$

A estas medidas se sumaron otras por parte de Felipe II y principalmente de Carlos II, con el fin de perfeccionar el control administrativo. A modo de lo que pasaba en villas y ciudades, en la ranchería les tocaría a los dueños de canoas elegir cada año un alcalde ordinario y cuatro diputados, con obligación de residencia, y un procurador. A su vez, el alcalde y los diputados nombrarían a un receptor y a un mayordomo, también entre los dueños de canoas, encargados de cobrar las multas infligidas. Para ser elector se necesitaría poseer por lo menos una canoa, con doce negros. En caso de litigio en materia de penas, se harían las apelaciones ante el gobernador. El alcalde y los diputados se reunirían en cabildo cada dos meses como mínimo, so pena de una multa de veinte pesos a favor de la cámara real y los gastos de ranchería, y se admitía la posibilidad de convocar a cabildo abierto para el examen de negocios graves. Las ordenanzas despachadas se asentarían en un libro encerrado en una caja de dos llaves, quedando una en manos del alcalde y la otra en las del diputado más antiguo. El Cabildo tomaría las decisiones adecuadas en cuanto a cualquier gasto y a la cobranza de los fondos necesarios. Esta se haría en conformidad con las haciendas de los dueños de canoas y no con el número de sus negros de concha,

64 Ibidem, t. 2, pág. 289.

65 Carta del rey a la Casa de Contratación de 12 de octubre de 1596; Ibidem, t. 2, pág. 357.

66 Cartas de 2 y 6 de agosto de 1596; Ibidem, t. 2, págs. 383, 387-388.

67 Ibidem, t. 2, pág. 392.

68 Ibidem, t. 2, págs. 454-455. 
por ser éstos de aptitud desigual. Sería de la incumbencia del alcalde y de los diputados nombrar, despedir y pagar su estipendio a los capellanes sin que pudiesen intervenir los prelados del distrito. ${ }^{69}$

Sabemos muy poca cosa sobre la instrucción religiosa impartida a los pescadores de perlas. Tan temprano como el 15 de abril de 1541, se preocupó de ellos el presidente del Consejo de Indias, pidiendo al obispo de Venezuela don Rodrigo de Bastidas que pusiera en la pesquería del Cabo de Vela a "una persona de calidad que tuviere cargo de justicia", ${ }^{70}$ pero no se le fijó ningún cometido en el ámbito religioso. Tiempo después, otro obispo, el dominico fray Juan Manzanillo, decidió la fundación de un convento de su orden en la Margarita, proyecto apoyado por la Corona. A juzgar por una carta con fecha del 27 de noviembre de 1582, el provincial Mateo de Ovando se había visto encargado de proseguir las diligencias al respecto. ${ }^{71}$ Fuera lo que fuere, veremos que una de las pocas voces que se levantaron para protestar en contra de los excesos infligidos a los negros pertenecía a un fraile de dicha congregación.

En cuanto a las atribuciones de los cabildos de pesquería, una de sus tareas más importantes consistiría en decidir quiénes se encargarían de descubrir nuevos ostrales, obligándoles a cumplir con lo decidido. En caso de descubrimiento, se reduciría durante tres años el quinto real sobre el producto a la décima parte. ${ }^{72}$ Entre los deberes del alcalde se contaba el de hacer vigilar las rancherías del anochecer hasta rayar el alba para protegerlas de las incursiones corsarias, designando a los centinelas de la atalaya. $\mathrm{Al}$ mes de acabadas las elecciones anuales, los flamantes alcaldes y diputados tomarían cuenta de la actuación de sus predecesores, so pena de una multa de cincuenta pesos. En ningún caso se concedería licencia de pesca a un dueño de canoa no radicado en ranchería bajo el control determinado por las leyes. De igual manera nadie, fuera de los dueños de canoa o de hacienda en la ranchería, podría tratar en ella. De modo que estos recintos se dedicarían plenamente a la pesca (Lib. IV, tít. XXV, leyes III a XXII).

69 Esta medida correspondería al deseo de los dueños de librarse de un excesivo control de la jerarquía eclesiástica.

$70 R O P V$, t. 1, pág. 173. Rodrigo de Bastidas, por muerte del gobernador Jorge Espira, pasó de Santo Domingo a Coro, cabeza de la gobernación y de su diócesis, para asumir el cargo de gobernador. Véase: Fernández de Oviedo, G.: Historia General y Natural de las Indias, págs. 54-55.

71 Ibidem, t. 2, págs. 152-153. Ya existía un convento franciscano en Cubagua desde 1527. Véase: Otte, E.: Las perlas del Caribe, pág. 258.

72 La Recopilación hace referencia a la real cédula de 30 de octubre de 1593. Ahora bien hubo un primer texto despachado en 5 de junio de 1591; véase: $R O P V$, t. 2, págs. 263-264. 
Ello subraya la importancia concedida por la Corona al control del quinto procedente de la pesca. ${ }^{73}$ Se intentó limitar los casos de fraude, que no serían pocos, con medidas de una peculiar exigencia. El desembarque de las canoas se verificaría en presencia de los oficiales reales, quienes no podrían ausentarse de las rancherías durante la estación de pesca. El indio o negro que incurriese en delito sería castigado con cien azotes y el destierro perpetuo de la pesquería. Si fuese libre el delincuente, se le impondría una multa de veinte mil maravedíes, echándole fuera. Se traerían las conchas a la casa fuerte, donde se abrirían en presencia de los oficiales reales, condenándose a los infractores indios, mulatos y negros a doscientos azotes y a diez años de galera, y a los españoles o mestizos a cien azotes y pérdida de sus bienes por primera vez y a doscientos azotes y remo perpetuo por segunda vez. De ser dueños de canoa y de esclavos, perderían todos sus bienes y se les desterraría perpetuamente de las Indias. Por si fuera poco, quienes abriesen las conchas habrían de entrar desnudos en la casa fuerte, trabajando únicamente bajo vigilancia de los oficiales reales y de los dueños o de sus representantes (Lib. IV, tít. XXV, leyes XL a XLII).

El deseo de proteger los intereses del fisco real podía resultar contraproducente. Así, se decidió pagar a los canoeros con perlas quintadas, suprimiéndoles el privilegio de llevar consigo a un negro cuya pesca les servía de salario. Ahora bien, arguyó Alonso Suárez del Castillo, si los canoeros no siguiesen disfrutando de este favor, no buscarían los lugares donde creciesen las mejores ostras y por lo tanto iría disminuyendo el quinto. ${ }^{74}$

Las perlas, según medidas previstas en 1527 por Carlos I y en 1620 por Felipe IV, se recogerían en cajones correspondientes a cada dueño, encerrados en una caja grande de tres llaves en poder del alcalde, del tesorero y del veedor, si lo hubiese, o del contador. Los dueños, con su propia llave, podrían a su conveniencia sacar las perlas de su cajón, apuntando la salida en un libro especial. En uno de estos cajones, de tres llaves también, se guardarían las perlas del quinto real. Sólo se sacarían para remitirlas a España en presencia de los oficiales reales y del alcalde de la ranchería. El envío se haría en un cofre debidamente sellado, con una memoria del contenido firmado por los oficiales y el maestre del barco. Se pondría dicho cofre en un cajón clavado y precintado cuya llave se entregaría al general o

73 E. Otte calculó que "el quinto de Cubagua arroja un total de 10328 marcos, lo que equivaldría a una producción de 11 877, 20 kilos, o sea, una media de cerca de 410 kilos anuales"; Las perlas del Caribe ..., pág. 54.

74 ROPV, t. 2, págs. 504-506. 
al almirante de la flota, o, de no ser posible, al capitán o maestre de la nao. Además los oficiales reales mandarían al Consejo de Indias una fe del contenido. Para mayor seguridad en contra de las expediciones enemigas, el gobernador y capitán general de Cartagena, antes de salir la flota, haría reconocer la costa por galeras y navíos de la armada (Lib. IV, tít. XXV, leyes XXLVI a XLVIII).

Tenía interés la Corona en que se descubriesen nuevos placeres antes de que se agotasen los ostrales ya explotados y la documentación evidencia esta preocupación. El 14 de agosto de 1520, informado de que ya no se hallaban tantas perlas en Cubagua, el Consejo de Indias avisó a los oficiales de la Real Hacienda que habrían de trasladarse a los nuevos ostrales descubiertos por la costa de Venezuela y de Santa Marta. ${ }^{75}$ El 25 de noviembre de 1575, se puso en conocimiento de los oficiales del río de la Hacha que se habían hallado "grandes pesquerías" en la isla de Coche que "es muy cercana a la de la Margarita", de modo que muchas de las canoas de su provincia y de la del Cabo de la Vela se fueron allí. Estos cambios justificaban el traslado de la Caja Real a la Margarita, donde los oficiales se instalarían como mejor conviniese para la cobranza del quinto ${ }^{76}$ Poco tiempo antes, el 2 de octubre de 1575, debido al desarrollo rápido de la pesca en las costas de la Margarita, se impartió la orden al tesorero y al contador del río de la Hacha de dirigirse hacia esa isla para tomar cuentas y mandar lo más pronto posible el producto del quinto a la Península. ${ }^{77}$ Fue necesario esperar hasta marzo de 1584 para que se creasen los puestos de tesorero, contador y factor en la Margarita, viniendo el primero de Nueva España. ${ }^{78}$ Los procuradores generales de la isla se valieron de los apuros financieros de la Corona para solicitar privilegios fiscales, a favor en particular de los descubridores de nuevos ostrales, pretextando su deseo de evitar cualquier disminución del quinto. Fue el argumento esgrimido por Pedro Luis de Vargas en 23 de septiembre de 1586. ${ }^{79}$

Lo inhóspito de la isla y las epidemias que aquejaban a los vecinos de sus diferentes valles, no favorecieron su desarrollo una vez agotados los ostrales de perlas. La carta dirigida por los nuevos alcaldes ordinarios de Nuestra Señora de la Asunción con fecha de 31 de agosto de 1751 vio en

\footnotetext{
75 Ibidem, t. 1, págs. 164-166.

76 Ibidem, t. 2, págs. 31-32.

77 Ibidem, t. 2, pág. 33.

78 Ibidem, t. 2, págs. 158-162.

79 Ibidem, t. 2, pág. 186.
} 
la recesión el castigo divino por la lascivia de los isleños. ${ }^{80} \mathrm{El}$ abandono de la pesca de perlas en los diferentes placeres como Ceriagua, Perlas, Barro, Los Frailes, La Sola y Los Testigos le parecía injustificado en 1749 a Baltasar Antonio Sanz, vecino de Cádiz de Cubagua, quien se ofreció para rastrear los fondos con redes de malla y copos tiradas por dos barcos con veintiocho hombres. ${ }^{81}$ No se dignó la Corona interesarse por esta proposición, quizá por haber perdido ya toda esperanza. ${ }^{82}$ Sin embargo el gobernador Alonso del Río y Castro procedió a otra experiencia señalada en Madrid el 22 de noviembre de 1759. Valiéndose de los indígenas de la isla, los guaiqueríes, hizo tres intentos de pesca remitiendo a la Península las perlas sacadas en una cajita de plata. Defraudado por el poco resultado, el funcionario aludió a la impericia de los indios y a su miedo a los tiburones. Necesitaba buenos buzos procedentes del exterior. En un primer momento se le contestó que no era cuestión de satisfacer dicha demanda. La única solución consistía en formar a los guaiqueríes. Otra carta del 21 de septiembre de 1761 le informó de la llegada de la cajita cuyas perlas se analizarían. ${ }^{83}$

Dicha sea la verdad, los diferentes gobernadores no dieron pruebas de mucho interés por el fomento de las posibilidades económicas de la Margarita. Dada la pobreza de la isla, sólo pensaban en una cosa, obtener su traslado a otro lugar.

\section{De los indios a los negros}

Así que no se dejó de buscar paliativos a las dificultades de la pesca. Los diferentes cronistas los describen detalladamente ya sea para dar un giro exótico a su relato, ya sea para protestar en contra de las condiciones de trabajo.

De creer a Garcilaso de la Vega, los incas conocían las perlas, pero no consintieron la explotación de los ostrales por lo perjudicial de su extracción para los hombres:

80 AGI, Caracas, 391.

81 La Corona autorizó la pesca de perlas con rastra en Cubagua en 1520. E. Otte suministra en su libro la primera descripción de uno de estos ingenios utilizado en 1568 en la Margarita. Las perlas del Caribe ..., pág. 44.

82 AGI, Caracas, 391.

83 Ibidem, Caracas, 140. 
“... porque los Incas (que siempre atendieron y pretendieron más la salud de los vasallos, que aumentar las que llamamos riquezas, porque nunca las tuvieron por tales), viendo el trabajo y peligro con que las perlas se sacan de la mar, lo prohibieron, y así no las tenían en uso".

Conocida es la propensión del mestizo a valorar la actitud de sus antepasados maternos. Si bien de un modo general la política incaica protegía a la gente del común, instrumento de la extensión territorial, hay que admitir que en el Tawantinsuyu no abundarían las pesquerías, excluyendo, quizá, el litoral de Manta, en el actual Ecuador. ${ }^{84}$

Antonio de Herrera expone los primeros obstáculos a la explotación de los ostrales de Cubagua. Siendo la isla casi desértica, los vecinos de La Española buscaron fuera la mano de obra idónea, encontrándola entre los lucayos ${ }^{85}$ "por ser grandes nadadores". ${ }^{86}$ De ahí el alto precio - hasta ciento cincuenta ducados - de estos indios, esclavizados por la codicia de los españoles. De un modo eufemístico, alude este cronista al surgimiento de tensiones: éstos "molestaban a los indios y les daban ocasión de ponerse en resistencia, con que se dificultaba la contratación". ${ }^{87}$ Para un mejor control de los pescadores, el almirante Diego Colón, a petición de los dueños de pesquerías, propuso que se herrase en una pierna o en un brazo a los indios "traídos de fuera". En una carta del 25 de julio de 1511, la Corona le dio su visto bueno siempre y cuando se actuase con la prudencia requerida en la materia: "de forma quello se faga con la menos pena de los yndios que ser pueda" ${ }^{88}$ Debido a la disminución de los lucayos, se hicieron diligencias para encontrar pescadores en los islotes de las costas de Tierra Firme. Comunicó el rey al obispo de Venezuela el 26 de junio de 1539 el proyecto ideado por el mariscal Diego Caballero, ${ }^{89}$ al que le interesaban las cuali-

84 Garcilaso de la Vega, Comentarios reales de los Incas, págs. 326-328.

85 Naturales del archipiélago llamado hoy día Bahamas. Véase más abajo lo que dice de ellos Las Casas en Brevísima relación de la destruición de las Indias, Edición de André Saint-Lu, Cátedra, Madrid, 1995. Otte señala que, pese a la prohibición de vender indios lucayos despachada por la Corona, fue "inmediatamente quebrantada por los mismos oidores de la audiencia real"; Las perlas del Caribe ..., pág. 115.

86 Antonio de Herrera, en lo que toca a la pesca de perlas en Cubagua, parece inspirarse de lo que dice Las Casas en Historia de las India; véase más abajo.

87 Herrera, A. de: Historia general de los hechos de los castellanos en las islas y Tierra Firme del mar Océano o Décadas, t. 1, pág. 504.

88 CDIRDCO, t. 32, pág. 263.

89 Este proyecto no era ninguna novedad de parte de Diego Caballero que ya en 20 de junio de 1519 había conseguido del licenciado Zuazo licencia para rescatar esclavos en la costa de Tierra Firme. Sobre este personaje y los demás que se dedicaron a esta actividad, véase: Gil, Juan : Mitos y utopías del Descubrimiento. 3. El Dorado, Alianza Universidad, Madrid, 1989, págs. 19 sq. 
dades de los indígenas de los Gigantes, islas situadas no muy lejos de las pesquerías del Cabo de la Vela,${ }^{90}$ que estaban encomendados al factor Juan de Ampiés, ${ }^{91}$ pero éste los desatendía. Buenos nadadores, les resultaría muy útil trabajar como pescadores para mantenerse. El prelado comprobaría la buena ejecución del permiso concedido al solicitante. ${ }^{92}$ Ahora bien, el verdadero beneficiario de la encomienda otorgada por el presidente de la Real Audiencia de Santo Domingo, Lázaro Bejarano, se opuso al proyecto. Optó entonces Caballero por otra posibilidad, la de acudir a los onotes, indios de la laguna de Maracaibo, por ser "criados en el agua". ${ }^{93}$ A cambio de su trabajo Caballero se comprometía a educarles en la religión cristiana. Otra vez, por cédula del 14 de julio de 1540 firmada por el cardenal fray García de Loayza, se confió al obispo la misión de cuidar del buen tratamiento de los onotes, quienes, por su trabajo libremente consentido, recibirían un salario fijado por el mismo religioso. ${ }^{94}$

Con el descubrimiento de los ostrales de la isla de Coche, a cuatro leguas de Cubagua, empezarían a llegar protestas por las condiciones de trabajo impuestas a los indios, viéndose obligada la Corona desde 1529 a adoptar las medidas de protección citadas por Herrera. Se prohibió la pesca fuera del verano e incluso de los días de bonanza ${ }^{95}$ y la faena no podría

90 Las Casas cita este grupo de islas, despobladas, como las de los Lucayos, por la codicia de los españoles, en las primeras páginas de la Brevísima Relación de la Destruición de las Indias. Se trata de Curaçao y de las islas vecinas. En Historia de las Indias, Lib. II, Cap. II, Las Casas da detalles sobre las islas de los Gigantes descubiertas por Alonso de Hojeda, apoyándose en Américo Vespucio, que acompañó al descubridor en su segundo viaje: "Entrando que entraron en una isla, la mayor de seis que hay e no más, desde Paria hasta Cuquibacoa, que hoy decimos Venezuela, dejada aparte la Margarita y otras isletas no de cuenta, y aquélla debía ser la que llaman los indios Curaçao, la penúltima luenga; éstas son seis islas que están en renglera, que distan de la tierra firme cuasi quince y veinte leguas". Llamaron así dicha isla, conocida después por Curaçao, por haber encontrado en ella hombres de "grande estatura". Afirma Las Casas que no había tales gigantes en estas islas (Historia de las Indias, t. 2, pág. 11).

91 Juan Martínez de Ampués o Ampiés, regidor de Santo Domingo en 1511, conquistó Curaçao en 1527 a instancias de la Real Audiencia. Actuó en contra de la reducción a la esclavitud de los indios de Tierra Firme, de modo que Demetrio Ramos hizo de él un émulo de Las Casas en su estudio "Un paralelo seglar del P. Las Casas: Juan de Ampiés", Anuario de Estudios Americanos, XXXIV, Sevilla, 1972, págs. 149 sq. Véase: Gil, J. : Mitos y utopías del Descubrimiento. 3. El Dorado, pág. 18. $92 R O P V$, t. 1, págs. 135-136.

93 G. Fernández de Oviedo hizo hincapié en sus costumbres: “... viven dentro del agua, sobre barbacoas e buhíos de madera altos, que debajo dellos andan y pasan canoas. Viven de pesquerías, e van e vienen a la ribera desta laguna, y rescatan e venden aquel pescado que matan, por maíz e por otras cosas ..."; véase su Historia General y Natural de las Indias, BAE 119, pág. 34.

$94 R O P V$, t. 1, págs. 155-156. Para más sobre la actuación de Diego Caballero, se consultará Otte, E. : Las perlas del Caribe ..., págs. 22 y 109.

95 Frente al agotamiento de los ostrales de Cubagua, el juez de residencia Francisco de Prado impuso en 1533 una veda que se renovó en los años siguientes. Otte, E. : Las perlas del Caribe ..., págs. 34-35. 
pasar de cuatro horas diarias ni realizarse a más de cinco brazas de profundidad. De quererse alcanzar ostrales más ricos, situados entre cinco y ocho brazas, se reduciría el tiempo de trabajo a tres horas, descansando los pescadores el resto del día y las fiestas. Para la recuperación de sus fuerzas, se les daría buen mantenimiento e incluso un cuartillo de vino cada día. ${ }^{96}$

Las precauciones tomadas por la Corona antes de otorgar los permisos solicitados no servían para nada. Se vio obligado Carlos Quinto a adoptar una actitud menos benévola, como aparece en una carta dirigida el 5 de junio de 1546 al licenciado Tolosa, juez de residencia de la provincia de Venezuela y Cabo de la Vela. Las condiciones de trabajo impuestas a los pescadores, admitió el monarca, acarreaban la muerte de muchos indios y negros. La culpa la tenía en parte el prelado de Santa Marta por no haber cumplido debidamente con la misión de protección que le había sido confiada antes del nombramiento de un obispo en la provincia de Venezuela. De entonces en adelante se condenaría a pena de muerte a cualquiera que enganchase a indios libres en las pesquerías en contra de su voluntad. Al obispo y al juez les incumbiría proteger a los esclavos, indios o negros, de los excesos mortales, ordenando incluso el cierre de las pesquerías. Las Audiencias nombrarían personas de confianza para vigilar por el buen trato de los esclavos y de los indios libres que aceptasen el trabajo de pescadores. ${ }^{97}$

El tenor de esta carta se debe, no cabe duda, a la actuación de Las Casas, evocada más abajo. Los dueños de pesquerías, como los de actividades mineras o agrícolas intensivas, recurrieron a otra posibilidad, el recurso a la mano de obra negra, iniciado desde hacía algún tiempo. Fue necesario activar el ritmo de suministro de estos trabajadores serviles, como consta en la respuesta con fecha de 4 de octubre de 1597 a la solicitud de Pedro Fajardo, nombrado gobernador de la Margarita. Pedía el envío rápido de cuatrocientos esclavos "por no haber indios en la dicha isla y ser muchas las canoas que hay en ella con que se pescan las perlas e irse acabando los negros que en ella se ocupan". Además, argüía el gobernador, se había dado la orden de mandar a doscientos esclavos a Cumaná, cuando en este lugar había pocas canoas. ${ }^{98}$

$96 R O P V$, t. 2, págs. 784-785. El Consejo de Indias adoptó estas medidas tomando en cuenta las proposiciones procedentes de los responsables administrativos de Santo Domingo. Corresponden exactamente al contenido de la carta mandada al rey por Diego Caballero con fecha de 6 de marzo de 1529. Véase CDIRDCO, t. 40, págs. 435-438.

$97 R O P V$, t. 1, págs. 220-224.

98 Ibidem, t. 2, pág. 391. 
Se buscaron también otros medios. Hacia 1527, el milanés Luis Lampunano (o de Lampiñán), hijo del conde Andrés Lampunano, propuso al emperador un ingenio destinado a sustituir a los pescadores, indios o esclavos, para alcanzar sitios más profundos y lograr así perlas en mayor cantidad y de mayor tamaño. Se había de tirar con una o dos carabelas. Si bien no facilita Herrera detalles al respecto, imaginaremos una especie de red metálica con lastre que rastrearía el fondo del mar. Obtuvo el arbitrista el monopolio de uso durante seis años a cambio de un tercio de las perlas pescadas para la Corona, con obligación de actuar de cinco brazas para abajo para no competir con los dueños de canoas cuyos indios o negros de concha no solían sumergirse más allá, aunque, como veremos, algunos sí lo hacían. ${ }^{99}$ Posiblemente la oposición de los dueños de canoas fue una de las causas del rápido abandono de tal proyecto. ${ }^{100}$ Otros inventores intentaron encontrar una solución al límite de las posibilidades humanas: el 2 de junio de 1585, consiguió Jusepe Bono el permiso de llevar a la Margarita "un ingenio de pescar perlas" de su invención ${ }^{101}$ y siete años más tarde, el 25 de junio de 1592, un francés, Domingo Bartolomé, alcanzó el mismo favor. Con su ingenio, llamado "tartana", el segundo pretendía sacar conchas de "mucho fondo a donde los negros no pueden entrar". ${ }^{102}$

La ley se acataba, pero no se cumplía, como lo ponen de manifiesto las crónicas. La descripción de Fernández de Oviedo, testigo ocular, entra en pormenores de gran interés. En cada canoa ${ }^{103}$ iban seis o siete esclavos indios, nadadores experimentados. Llegados al lugar de pesca, sólo uno de ellos se quedaba en la canoa para mantenerla fija y atender a sus compañeros que volvían del fondo para entregar las ostras recogidas en una bolsa atada a la cintura o al cuello. Después de un rato de descanso, se echaban de nuevo al mar, y así hasta el final de la faena. Para quedar en el fondo, solían atarse dos piedras a cada costado con una cuerda, que se quitaban para salir del agua. Los más hábiles de los indios lograban permanecer un cuarto de hora abajo, e incluso más los mejores. Al regresar ponían las ostras en poder del señor o de su mayordomo. Agotado el ostral, pasaban

99 Efectivamente le pusieron pleito a Luis de Lampiñán los cubagüenses, como relata Otte, E.: Las perlas del Caribe ..., pág. 34 .

$100 R O P V$, t. 2, págs. 647-648.

101 Ibidem, t. 2, págs. 179-180.

102 Ibidem, t. 2, págs. 292-298.

103 Para una descripción detallada de estas canoas, véase: Otte, E. : Las perlas del Caribe ..., pág. 46. 
las canoas a otros sitios hasta que se regenerase. ${ }^{104}$ En la costa del Río de la Hacha, precisa López de Velasco, las canoas se alejaban hasta una legua del litoral ${ }^{105} \mathrm{y}$, de creer a Acosta, en los mismos lugares los buzos bajaban hasta nueve e incluso doce brazas. Insiste en el frío que pasaban y en lo difícil que era mantenerse en el fondo entre un cuarto de hora y treinta minutos. Sus dueños les imponían una dieta muy pobre y una gran continencia, con el propósito de preservar sus capacidades. ${ }^{106}$ Más tarde, hacia 1630, el carmelita Antonio Vázquez de Espinosa se demoró en estas prácticas, refiriéndose a las pesquerías de la Margarita. Ahí se utilizaban fragatas de vela latina, con doce negros de pesca y el capitán, un negro diestro en el oficio. Españoles eran el piloto, o canoero, y el mayordomo. Estas canoas se alejaban de la costa de una legua y media a dos y más. Cuando los pescadores regresaban a tierra, los señores los encerraban con llave en un cuarto grande "a modo de enfermería, que llaman cárcel", "porque aun para la pesca de las perlas es necesaria la castidad". Por si fuera poco, se castigaba a los buzos que no hubieran traído bastantes ostras perleras:

"Para los que no han sacado a gusto del amo o son traviesos, tienen en sus dormitorios o cárceles, grillos y prisiones, y los castigan, azotan y brean ${ }^{107}$ cruel e inhumanamente, acción bien ajena de la profesión cristiana, si bien para lo que toca a aquel oficio todo es menester, porque de otra suerte no harían cosa". ${ }^{108}$

Cobo parece inspirarse, en 1653, en los datos suministrados por el carmelita. Estas canoas, asegura, llevaban hasta veinte y treinta esclavos negros ya que, dadas las dificultades de la pesca, se había sustituido a los indios. Para que tuvieran el aliento necesario, los señores les imponían continencia, encerrándoles la noche antes de salir al mar. Describe así el jesuita las faenas de los buzos:

"Entran los buzos en el agua con unos guantes de cuero, para que los filos de las conchas, que son agudos, no les corten y lastimen las manos; un cuchillo para arrancarlas y una taleguilla hecha de red, en que echarlas, la cual, para que esté zafa y no se les enrede y los detenga, tiene hecha la boca de una varilla correosa como mimbre, y así con gran presteza, en arrancando las ostias, las echan en la red, y cuando está lle-

$104 R O P V$, t. 2, pág. 206.

105 López de Velasco, J.: Descripción universal de las Indias, pág. 77.

106 Acosta, J. de Historia Natural y Moral de las Indias, pág. 109.

107 Aquí en el sentido de "maltratar".

108 Vázquez de Espinosa, Antonio: Compendio y descripción de las Indias occidentales, Edición de B. Velasco Bayón, BAE 231, Editorial Atlas, Madrid, 1961, págs. 40-41. 
na la tiran del barco al cual está asida con una cuerda, haciendo para ello señal el buzo con un tirón que da en la dicha cuerda. Ultra del gran trabajo que es para los buzos esta pesca, andan siempre expuestos a muy gran riesgo de ser comidos de tiburones y marrajos, que son las fieras más crueles y carnívoras que cría el mar, como en efecto se han comido algunos". ${ }^{109}$

El jesuita fue el segundo, después de Las Casas, en denunciar este peligro, que recalcó a mediados del siglo XVIII Antonio de Ulloa tratando de las pesquerías de Panamá. El buzo negro, apuntó el oficial y científico español, ${ }^{110}$ tenía que suministrar a su señor cierto número de perlas, descontando las de mal aspecto. Le pertenecían las demás que vendía al dueño por un precio muy moderado. Se interesó en particular Ulloa por los peligros que acechaban a los pescadores:

"Los tiburones y tintoreras, ${ }^{111}$ que son monstruosa magnitud, hacen pasto propio los cuerpos de los pescadores. Y las mantas ${ }^{112} \mathrm{o}$ los comprimen envolviéndolos con su cuerpo o cargando todo su peso sobre ellos contra el fondo; parece, no sin razón, que el haber dado nombre de manta a este pescado nació de su figura y propiedad, porque, siendo aquélla en lo extendido y grande como una manta, hace el mismo oficio que está envolviendo en sí al hombre u otro animal que coge, y estrechándolo de tal suerte, que le hace rendir el último aliento a fuerza de comprimirlo ..."

A pesar de tener cuchillos para defenderse y ahuyentar al pez, de vigilar las aguas el negro caporal y de zambullirse en caso de necesidad para socorrer a los pescadores agredidos, "suelen quedar sepultados en los buches de estos peces algunos negros y otros baldados con alguna pierna o brazo menos, según la parte por donde les cogió". ${ }^{113}$

Ha llegado el momento de contemplar lo dicho por Las Casas acerca de esta actividad que, con su estilo hiperbólico, calificó de infernal. ${ }^{114} \mathrm{La}$ codicia llevaba a los españoles a portarse como auténticos verdugos frente a los indios pescadores:

109 Cobo, B.: Historia del Nuevo Mundo, t. 2, pág. 133.

110 Participó en 1735 con Jorge Juan, como representante de la Corona española, en la expedición de La Condamine para medir el meridiano en la Real Audiencia de Quito.

111 Las tintoreras son una especie de tiburones.

112 Raya de gran dimensión de los mares tropicales (manta birostris).

113 Ulloa, Antonio de: Viaje a la América meridional, Ed. de Andrés Saumell Lladó, Dastin Historia, Madrid, 2002, t. 1, págs. 172-174.

114 Miguel Acosta Saignes menciona la protesta de Las Casas y ciertas reales cédulas destinadas a que sacasen del agua los canoeros a los negros ahogados, de las que trataremos abajo, "porque el descuido con los cadáveres engendraba la pérdida de nuevos esclavos, es decir, representaba un descalabro económico para los dueños y por ende para el fisco, el cual no podía recoger el quinto de las perlas" ; in : Vida de los esclavos negros en Venezuela, Casa de las Américas, La Habana, 1978, pág. 169. 
"La tiranía que los españoles ejercitan contra los indios en el sacar o pescar de las perlas es una de las crueles y condenadas cosas que pueden ser en el mundo. No hay vida infernal y desesperada en este siglo que se le pueda comparar, aunque la de sacar oro en las minas sea en su género grandísima y pésima". ${ }^{115}$

Evoca el fraile no sólo la dificultad de la pesca sino también los malos tratos infligidos por el canoero. Auténtico "verdugo español", les da puñadas a los indios y les echa al agua por los cabellos para que tornen a pescar. De noche los dueños les ponen cepos para evitar su huída. La comida es mala e insuficiente. Pero lo peor son los tiburones y marrajas ${ }^{116}$ que se tragan un hombre entero. Los que se salvan de tal peligro "comúnmente mueren de echar sangre por la boca, y por el apretamiento de pecho que hacen por causa de estar tanto tiempo y tan continuo sin resuello, y de cámaras que causa la frialdad". Así se acabaron los lucayos, vendidos como esclavos por ser buenos nadadores, teniéndolo prohibido la justicia, y murió gran número de indios de otras regiones. ${ }^{117}$

En una carta dirigida a la Corona en 1571, otro dominico, fray Jerónimo de Santander y Cárcano, se explayó con una violencia parecida sobre la suerte de los pescadores. Consumidos los lucayos, y huyendo los otros indios de tal existencia, acudieron los dueños de canoas de Cubagua a esclavos negros de diez años para arriba, pero no mayores de veinticuatro. Salían a la vela cada mañana entre siete y ocho canoas con cincuenta o sesenta negrillos hasta dos leguas de la costa, donde echaban las anclas. Los pormenores anotados coinciden con lo descrito en las crónicas o por Las Casas, salvo el hecho de que a menudo les salía sangre por las orejas a los pescadores de tanto quedarse en el agua. ${ }^{118}$

La carta mandada al rey por don Antonio Collatupa, cacique de Cajamarca, el 17 de marzo de 1664, tendría que ver con las pesquerías de

115 E. Otte cita esta evocación en su libro Las perlas del Caribe ..., pág. 25.

116 Las marrajas (o marrajos) son una especie de tiburones muy feroces.

117 Las Casas, B. de: Brevísima relación de la destruición de las Indias, págs. 144-145. Se refiere también Las Casas a la extracción de los lucayos de sus islas para la pesca de las perlas en Cubagua en Historia de las Indias, L. II, cap. XLV (op. cit., t. 2, pág. 111) : "Y así fenecieron tanta multitud de gentes que había en tantas islas como queda dicho, que llamamos de los Lucayos o Yucayos". Acabados los lucayos "acordaron [los españoles] de hacer armadas de dos y de tres navíos, para ir a saltear las gentes de aquella tierra firme y traerlas a esta isla, y hacer dellos lo que de los naturales della hicieron y de los que trujeron de las dichas islas de los Yucayos" ; L. III, cap. XXXIV, pág. 257. Por fin expone de nuevo las condiciones de vida de los pescadores, aunque de una manera un poco más detallada que en la Brevísima relación en el cap. CLXV del mismo libro (t. 2, págs. 578-579).

118 AGI, Lima, 314, fol. 8 r-9 a. 
perlas de Manta. Se levantó contra esta actividad, arguyendo los textos de 1541 que rezaban lo siguiente:

"Y si les pareciere que no se les puede escusar a los yndios y negros el peligro de muerte, cesse la pesquería. Porque estimamos en mucho mas, como es razon, la conservacion de sus vidas, que el interes que nos puede venir de las perlas" ${ }_{119}$

Según parece pues, los indios y los negros de la costa del Perú seguían pagando con su vida la codicia de los españoles, y lo interesante es que lo dijera un "natural", aconsejado en este caso por algún religioso.

Sin embargo Felipe II, en una cédula del 2 de Junio de 1585, había ordenado que la pesquería de perlas se hiciese únicamente con negros y quien obligase a un indio a ella incurriría en pena de muerte. Aunque de mucha gravedad, la medida no surtió efecto. La reanudó Felipe III en 1601 sin conseguir mejores resultados. Despachó el 26 de mayo de 1609 otra decisión con el fin de prohibir el empleo de indios para sacar perlas, aunque fuesen voluntarios, al igual que se prohibía usar mano de obra indígena en los trapiches e ingenios de azúcar. ${ }^{120}$

En teoría sólo quedaba una posibilidad, el recurso a los negros. Ello incitó a varios vecinos de la Margarita a solicitar esclavos con ciertas condiciones de pago. El 2 de abril de 1582 Luis de Leiva logró el permiso para mandar un barco de Sevilla a la isla con dos partidas de esclavos, una de cincuenta negros de Cabo Verde y Guinea libres de derechos y otra de ciento cincuenta de varias licencias concedidas a otras personas. ${ }^{121}$ Pedro Luis de Vargas, por ejemplo, pidió en 15 de enero de 1586 el envío de dos mil negros, con un plazo de hasta cuatro o cinco años para el pago, "con los cuales se descubrirán nuevos ostiales, porque los descubiertos se van ya apurando". También podrían cultivar la tierra, aliviando así a los indios. ${ }^{122}$ A fines del XVI y en los primeros decenios del siglo posterior, despachó el Consejo de Indias varias cédulas en relación con el envío de esclavos a las pesquerías de perlas y en particular a las de la Margarita. Tales eran las necesidades que los dueños de canoas se valían del contrabando, según atestiguó el fiscal de la Audiencia de Santo Domingo en febrero de 1589,

119 AGI, Lima, 33A, fol. $1 \mathrm{r}$. ley XI.

120 Recopilación de leyes de los Reinos de Indias, Lib. III, tít. 25, ley XXXI; Lib. VI, tít. XIII,

$121 R O P V$, t. 2, págs. 147-148.

122 En Documentos para el estudio de los esclavos negros en Venezuela. Selección y estudio preliminar de Ermila Troconis de Verascochea, Caracas, 1969, pág. 70. 
evocando el caso de sesenta y tres esclavos escondidos en dos navíos para defraudar al fisco. ${ }^{123}$ Los portugueses vieron el provecho que podrían sacar de este comercio. Así, el 17 de marzo de 1589, Alvaro Méndez de Castro, residente en Lisboa, beneficiario del asiento de contratación de esclavos procedentes de Cabo Verde y Guinea, obtuvo del rey una orden de detención contra Francisco Gómez, vecino de Sevilla, con quien había formado una compañía para mandar a doscientos diez esclavos y varias clases de mercaderías a la Margarita, informando que su socio se había esfumado con el producto de la venta. ${ }^{124}$ El 19 de junio de 1620, don Bernardo de Vargas Machuca, en nombre de los vecinos de la isla, solicitó mil esclavos para las canoas. ${ }^{125}$ En 1627, el Consejo de Indias transmitió a la Casa de Contratación de Sevilla las peticiones del gobernador. Los vecinos necesitaban, para doce canoas de pesca, ciento cincuenta negros de 15 a 25 años, la edad más favorable para los buzos, con cincuenta negras para su servicio, comprometiéndose a pagar su valor a los seis años. No era cuestión de desestimar la demanda, como ocurrió cuatro años antes, lo cual había acarreado una grave pérdida para el fisco real. Dicha administración, según afirmó el 9 de noviembre, entró en relación con el asentista Manuel Rodríguez Lamelo para que atendiese la petición en las mejores condiciones. ${ }^{126}$

Como hemos dado a entender, las actividades pesqueras de las islas originaron una dependencia frente a los mercaderes, no sólo en materia de esclavos sino también en toda clase de víveres para su manutención y de aparejos destinados a las canoas como jarcia, brea, velas, etc. Para los sevillanos no era un negocio despreciable, a juzgar por las solicitudes de armar barcos con el fin de satisfacer la demanda. ${ }^{127} \mathrm{El} 22$ de enero de 1583, se le dio licencia a Gaspar de Peralta para mandar una fragata de setenta toneladas a la isla de la Margarita y al Río de la Hacha, que navegaría en conserva con la flota para Nueva España. ${ }^{128}$ Los vecinos de la Margarita a menu-

123 AGI, Santo Domingo, 51, R. 12, N. 110, 1.

$124 R O P V$, t. 2, págs. 226-228.

125 AGI, Santo Domingo, 26, en AGI Sevilla, Audiencia de Santo Domingo, Investigaciones Hmno Nectario María, salón de Investigadores, t. 1, pág. 239.

126 AGI, Contratación, 5173. Ubicamos la carta merced en un dato encontrado en: Vila Vilar, Enriqueta: "Posibilidades y perspectivas para el estudio de la esclavitud en los fondos del Archivo General de Indias”, Archivo Hispalense, T. 68, número 207-208, Sevilla, 1985, págs. 252-272, pág. 267.

127 Para más sobre el comercio de las perlas en Sevilla, se consultará Otte, E., Las perlas del Caribe ..., págs. 68-78. El mismo autor suministra en el apéndice de su libro, págs. 479-488, listas de mercancías importadas en Cubagua en 1528-1529 por varias carabelas.

$128 R O P V$, t. 2, págs. 156-157. 
do tenían sus corresponsales en la ciudad hispalense que se encargaban no sólo de reunir las mercancías sino también de encontrar el tipo de navío adecuado, de entre setenta y ochenta toneladas. Don Luis de Leiva solía tratar con Pedro de Palacio de la Maza, quien obtuvo el 27 de marzo de 1584 otro permiso para mandar un barco en conserva con la flota. ${ }^{129}$ Se estableció de este modo una red económica, lo cual incitó a ciertas familias de mercaderes a mandar a miembros suyos a la isla para dedicarse a la pesca, con lo cual conseguían dominar del todo este sector, disminuyendo los costes de producción. Según una licencia despachada el 7 de abril de 1584, pudo Gonzalo Milano armar un navío de ochenta toneladas destinado a su hermano instalado en la isla. ${ }^{130}$ Estaban dispuestos los beneficiarios de la pesca a aceptar mayores riesgos con el fin de conseguir a menor precio lo necesario para sus actividades. En 18 de julio de 1584, el gobernador, don Juan Sarmiento de Villandrando, obtuvo licencia para que su poderhabiente le enviase un barco sin obligación de llevar a bordo maestre ni piloto examinado ni artillería. ${ }^{131}$ Además urgía establecer una periodicidad en el suministro, para evitar toda ruptura perjudicial para los particulares y por lo tanto para los ingresos fiscales. Fue ésta la preocupación del licenciado Francisco Manso de Contreras, como procurador general. Una real cédula del 5 de junio de 1591 autorizó durante nueve años la salida de Sevilla o Cádiz de dos barcos anuales con destino a la Margarita. No podrían llevar mercancías fuera de las permitidas y navegarían también en conserva con la flota. ${ }^{132} \mathrm{El} 4$ de octubre de 1600 se concedió una prórroga de seis años. ${ }^{133}$

Ser dueño de una canoa de pesca requería una importante inversión financiera, según aparece en las escrituras de venta. Merece nuestra atención una de ellas, firmada en 18 de enero de 1612 por Daniel Cáncer y su esposa, como vendedores, y por don Bartolomé de Vargas Machuca, residente en la Margarita, como comprador. Además de la canoa y de sus pertrechos, de una canoita, de casas en los puertos del Tirano, de Coche, de las puntas de Mosquitos, de Piedras y de Macuanao, de dos mulas, de tres pipas con arcos de hierro, de treinta botijas, de barriles nuevos, de una caja de perlas de dos llaves, de un peso de pesar perlas, de una cadena de hierro con cuatro collares (¿para sujetar a los esclavos en caso de necesidad?), de

\footnotetext{
129 Ibidem, págs. 163-164.

130 Ibidem, pág. 165.

131 Ibidem, págs. 169-170.

132 Ibidem. págs. 265-266.

133 Ibidem, págs. 450-451.
} 
otros instrumentos de pesca y de cocina (pilón, piedras de moler posiblemente para el maíz o la mandioca con que se hacía cazabe), ${ }^{134} \mathrm{el}$ acta concernía a quince negros para sacar perlas, un negro arriero y dos negras que servirían de cocineras. Uno de ellos era criollo de la isla y los otros eran de nación biafara, bran, cocolí, y principalmente angola. Ya sabemos que estos pescadores no podían pasar de los 25 años sin correr riesgo y se les habría escogido entre negros procedentes del litoral africano, donde muchos pueblos vivían de la pesca e incluso de la extracción de ostras en los manglares. ${ }^{135} \mathrm{El}$ conjunto se estimó a diez mil quinientos pesos de perlas de a diez reales cada peso, que el comprador pagaría a plazos, abonando las deudas de los vendedores. ${ }^{136}$

Los dueños no concedían una excesiva importancia a los pescadores negros, considerándoles como meros bienes de su pertenencia. Ni siquiera se preocupaban por sacar de los ostrales los cuerpos de los ahogados, lo cual atraía a muchos tiburones que ponían en peligro la vida de los buzos. Con este motivo se les impuso a los canoeros la obligación de buscar el cuerpo de los difuntos antes de seguir la pesca. En caso de hundirse una canoa, las otras la socorrerían sin dilación. Se prohibió echar la desbulla en el ostral por atraer a estos terribles peces. Además cada canoa llevaría un anzuelo para pescarlos.

Hartos de los peligros, de las sevicias y del exceso de trabajo, se alzaban a veces los negros de alguna canoa y huían con ella, siendo preciso ordenar que las demás la siguiesen hasta tomarla. ${ }^{137}$ Con este motivo, y no sólo para la defensa contra los corsarios, requirió la Corona que los canoeros y mayordomos tuvieran espada y arcabuz y estuvieran bien apercibidos en pólvora y municiones, "porque así podrán ocurrir todos juntos al inconveniente de alzarse tantos Negros, e invasiones de Corsarios, que con lanchas pequeñas han hecho mucho estrago en las pesquerías". ${ }^{138}$ En 1600, el

134 Según Las Casas, la comida de los pescadores se componía de pescado y "pan cazabi, y algunos maíz (que son los panes de allá); Brevísima relación ..., pág. 144. Es de suponer que la dieta de los esclavos negros era idéntica.

135 Es el caso de Joal, antigua factoría portuguesa en el actual Senegal, o del poblado lacustre de Ganvié, en la república de Benín.

136 AGI, Escribanía de Cámara, 1013. Ubicamos también este dato merced a E. Vila Vilar: "Posibilidades y perspectivas para el estudio de la esclavitud en los fondos del Archivo General de Indias", pág. 267.

137 Recopilación de leyes de los Reinos de Indias, Lib. IV, tít. XXV, leyes XXXV a XXXVIII.

138 Ibidem, Lib. IV, tít. XXV, leyes XXVII-XXVIII. En 1578, el pirata inglés Oxenham, con la ayuda del jefe cimarrón Juan Vaquero, se apoderó de las islas de las Perlas, en el Pacífico, llevándose a varios buzos negros. 
capitán Alonso Suárez del Castillo, procurador general de la Margarita, se quejó amargamente de la actitud de los pescadores negros opinando que, debido a la excesiva libertad que se les concedía, huían al monte, en donde resultaba casi imposible encontrarlos. Por ello solicitó el permiso para contratar a doce indios guaiqueríes, naturales de la isla, para coger a los esclavos fugitivos, lo cual le facilitó una real cédula del 25 de septiembre de $1600 .{ }^{139}$ La ciudad de Cumaná manifestó su desaprobación frente a la prohibición por la Audiencia de Santo Domingo de emplear indios en la pesca de perlas cuando la voluntad real consistía en evitar tan sólo que se les obligara a pescar en contra de su voluntad. Ya no se sacaban perlas desde hacía dos años porque los negros daban pruebas de muy mala voluntad, ocultando incluso los ostrales descubiertos para dedicarse a sus conucos y sementeras y andar con las negras. Por eso se suplicaba a la Corona que se devolviese a los dueños de canoas la posibilidad de acudir a indios asalariados. El 15 de febrero de 1613, se les informó de que se estaba contemplando el asunto pero un año después, el 4 de febrero de 1614, los vecinos de Cumaná y de la Margarita reanudaron su petición de emplear a los indios guaiqueríes. ${ }^{140}$ Además se planteaba otro problema, el de un posible levantamiento general de los negros de las pesquerías, evocado por el antiguo gobernador de la Margarita, Bernardo de Vargas Machuca, el 8 de septiembre de 1627. No les costaría mucho trabajo apoderarse de la ciudad de Nuestra Señora de la Asunción. ${ }^{141}$ A esta amenaza se añadía la de los corsarios. También en la isla se manifestaba esta doble psicosis recurrente experimentada en los centros urbanos de las costas tanto del Atlántico como del Pacífico.

Esta vez no se le podía acusar a Las Casas de haber incurrido en un fácil abultamiento: no cabe duda de que la pesca de perlas en Cubagua originó en gran parte la desaparición de los lucayos y de otros pueblos de indios de la costa de Venezuela. Cuando la Corona, prisionera de sus contradicciones, tomó conciencia de la realidad, ya era demasiado tarde. ¿Cómo renunciar a uno de los quintos más fructuosos, pese a lo reducido de las áreas de producción? Se contentó con favorecer abiertamente la sus-

$139 R O P V$, t. 2, págs. 447-448.

140 AGI, Santo Domingo, 190, doc. 23. ¿Tenían estos indios una relación con el pueblo de un cacique de la costa llamado Guaigueri, a quien evoca G. Fernández de Oviedo en su Historia General y Natural de las Indias, BAE 119, pág. 37?

141 AGI, Santo Domingo, 26, in : AGI Sevilla, Audiencia de Santo Domingo, Investigaciones Hmno Nectario María, salón de Investigadores, t. 1, pág. 277. 
titución de los naturales por esclavos negros, sometidos a drásticas condiciones de vida, no obstante tímidas ordenanzas lenificativas. Pero, a diferencia de lo que pasaba en las minas y en las plantaciones, se necesitaban sólo jóvenes, muchachos en su mayoría, condenados por la codicia de los amos y el fisco real a una despiadada deshumanización y a una muerte inexorable, fuera a causa de los estragos físicos generados por el oficio, o por los terribles "dientes del mar". Tal era el precio del adorno de las damas cortesanas y de las sagradas imágenes, e indirectamente de cierto tipo de metaforización petrarquista.

Recibido el 21 de mayo de 2008 Aceptado el 4 de noviembre de 2008 


\section{Lugares citados}

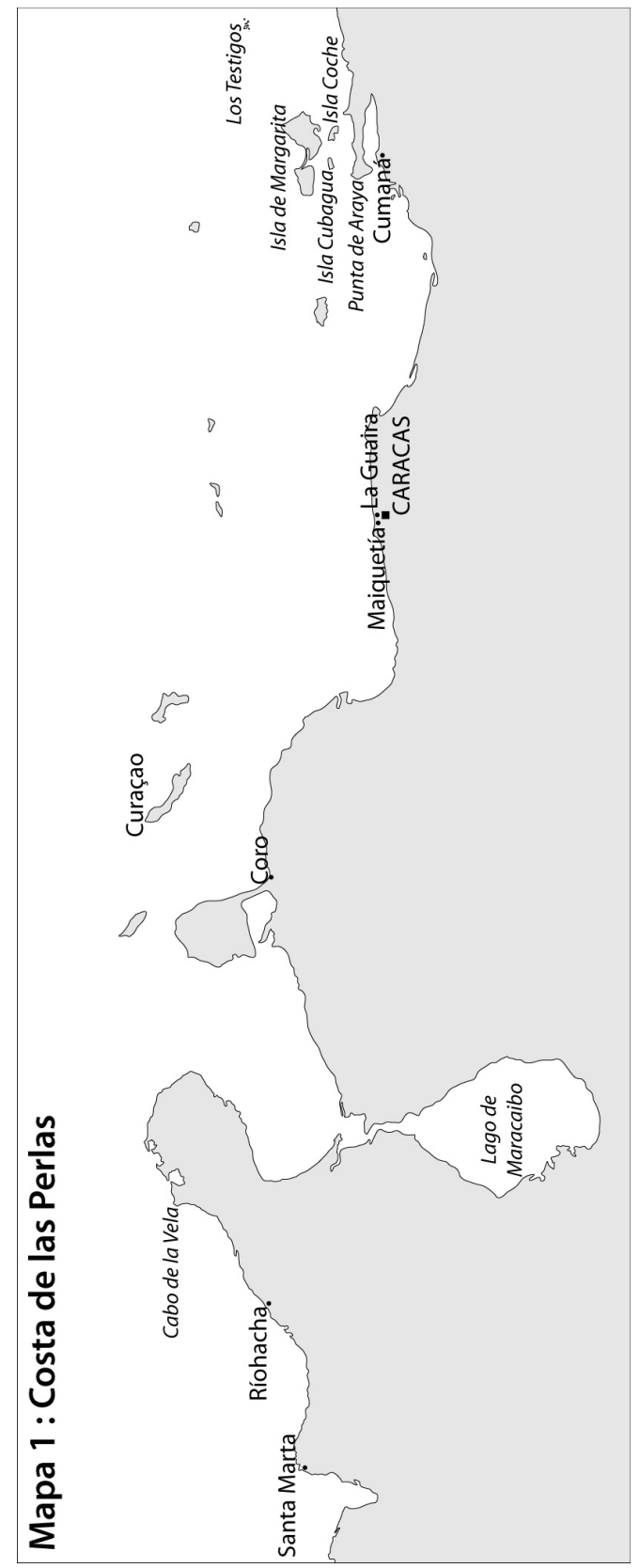




\section{Mapa 2 : Islas de las Perlas}
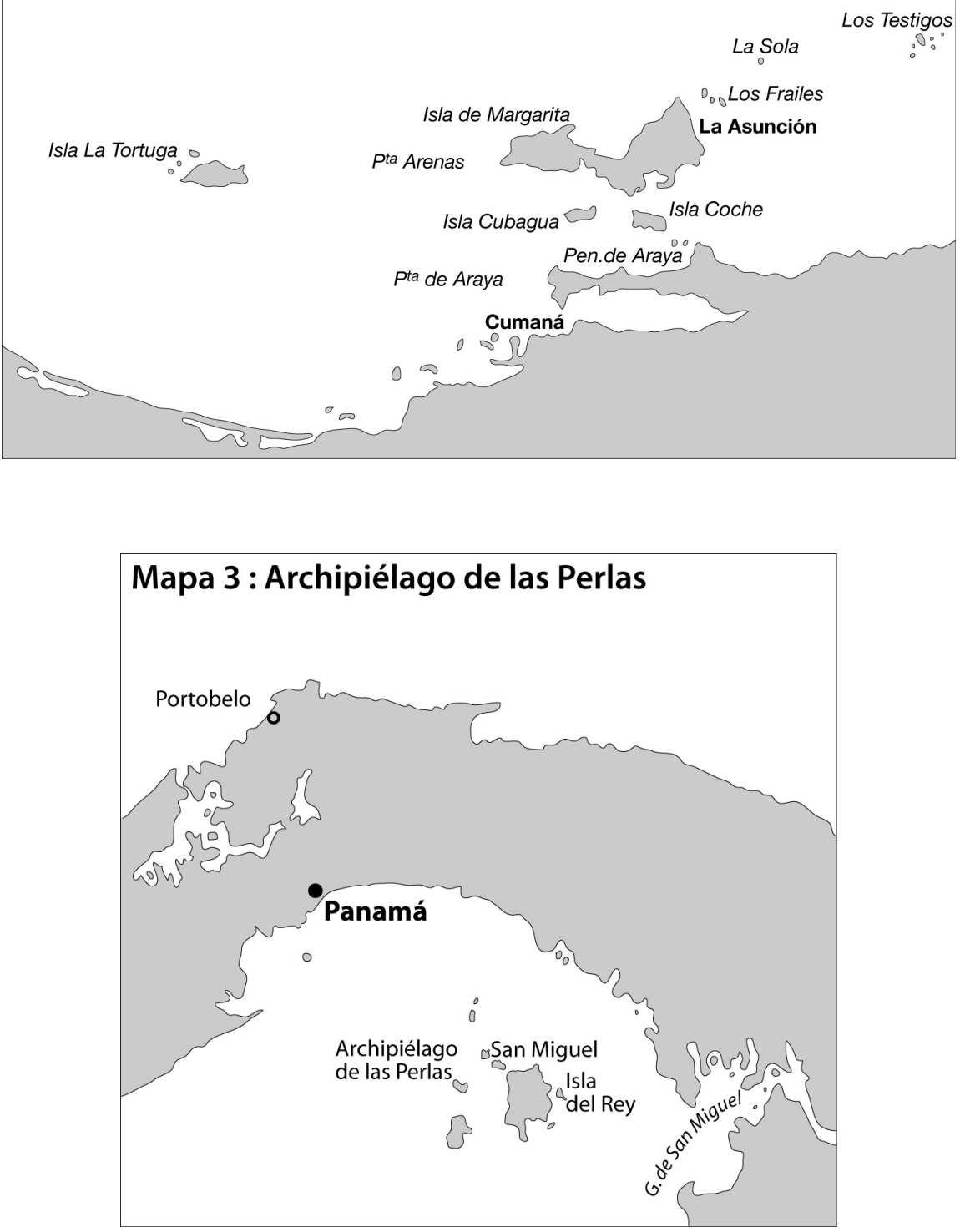